\title{
Pengaruh Political Connection terhadap Cumulative Abnormal Return dan Trading Volume Activity pada Pemilihan Presiden 2019 (The Influence of Political Connection on Cumulative Abnormal Return and Trading Volume Activity in the 2019 Presidential Election)
}

Eldam Pradana $^{{ }^{*}}$, Sudrajat ${ }^{2}$, Pigo Nauli ${ }^{3}$, Yuliansyah Yuliansyah ${ }^{4}$

Jurusan Akuntansi, Fakultas Ekonomi dan Bisnis, Universitas Lampung, Bandar Lampung 1,2,3,4 eldampradana83@gmail.com ${ }^{1 *}$, drajat239@gmail.com² ${ }^{2}$,pigonauli@gmail.com ${ }^{3}$,

yuliansyah@feb.unila.ac.id ${ }^{4}$

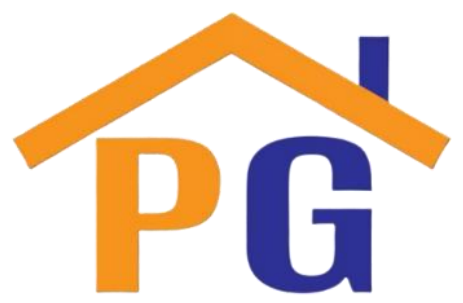

\begin{abstract}
Purpose: This study aimed to identify the impact of Political Connection on Cumulative Abnormal Return (CAR) and Trading Volume Activity (TVA) for companies that associate with political figures in the presidential election of 2019.
\end{abstract}

Research methodology: This study used quantitative methods, with a population of 25 companies on the Indonesian stock exchange, through daily stock prices.

Result: This investigation showed no significant difference in the Cumulative Abnormal Return between before and after the

Riwayat Artikel

Diterima pada 8 April 2021 Revisi 1 pada 12 April 2021 Revisi 2 pada 9 Mei 2021 Revisi 3 pada 20 Mei 2021 Disetujui pada 27 Mei 2021 announcement of the Constitutional Court. Then, there was no significance value on Trading Volume Activity and Cumulative Abnormal Return between before and after the announcement of General Election Commissions.

Limitations: In this study, the limitation is observation time which is only 36 days. The number of samples is limited, which only 25 companies with the scope of research of companies that have affiliations with the winners of the 2019 general election.

Contribution: This research implicates companies affiliated with politics. This is in the 2019 general election against the winners of the general election in 2019.

Keywords: Political Connection, Cumulative Abnormal Return, Trading Volume Activity

How to cite: Pradana, E., Sudrajat., Nauli, P., \& Yuliansyah, Y. (2021). Pengaruh Political Connection terhadap Cumulative Abnormal Return dan Trading Volume Activity pada Pemilihan Presiden 2019. Jurnal Studi Pemerintahan dan Akuntabilitas, $1(1), 83-95$.

\section{Pendahuluan}

Undang-Undang Republik Indonesia Nomor 40 Tahun 2007 tentang Perseroan Terbatas Pasal 1 menyatakan bahwa Perseroan Terbatas yang selanjutnya disebut perusahaan adalah unsur hukum yaitu perusahaan didirikan berdasarkan aturan untuk melakukan kegiatan usaha dengan modal yang disetujui yang dipisahkan seluruhnya menjadi bagian-bagian dan memenuhi kebutuhan yang ditentukan dalam undang-undang ini dan pedoman pelaksanaannya. Pada umumnya, perusahaan mungkin akan memperoleh manfaat dan bantuan pemerintah dari para pendukung keuangan.

Perusahaan yang didirikan memiliki tujuan tertentu. Menurut Martono dan Harjito (2005) ada tiga tujuan perusahaan didirikan. Pertama, untuk mencapai manfaat terbesar atau manfaat paling ekstrem. Kedua, menyejahterakan pemilik perusahaan atau investor. Ketiga, menaikkan nilai perusahaan yang tercermin dari nilai perusahaan. Tiga tujuan perusahaan tersebut tidak jauh berbeda. Hanya saja, aksentuasi yang perlu dicapai setiap perusahaan berbeda satu sama lain. Semakin signifikan peran pasar modal dalam perkembangan ekonomi suatu negara, maka akan semakin penting isu pasar modal 
yang mempengaruhinya. Isu dan kejadian politik tampaknya tidak dapat dipisahkan dari reaksi yang terjadi di pasar modal (Asmita, 2005).

Kegiatan politik menjadi salah satu aspek perkembangan perekonomian suatu Negara, melalui kebijakan moneter dan fiskal. Hal ini di buktikan oleh penelitian yang di lakukan oleh Coulomb dan Sagnier (2014): "bagian politik yang lebih besar mempengaruhi tindakan keuangan" menyiratkan bahwa "masalah pemerintah adalah bagian terbesar yang mempengaruhi pergerakan moneter". Contoh yang berpengaruh luas adalah strategi presiden Donald Trump dalam penetapan tarif perdagangan internasional, yang pengaruhnya dirasakan oleh Cina, Eropa, dan termasuk Indonesia yang merasakan dampak secara tidak langsung oleh kebijakan tersebut, yang berdampak pada melemahnya nilai tukar mata uang rupiah terhadap mata uang dolar Amerika (Fauzia, 2018). Peristiwa politik dan ekonomi merupakan kesatuan yang tidak bisa di pisahkan dalam proses perkembangan dan kemajuan suatu negara. Politik bertujuan untuk merumuskan sebuah kebijakan dan salah satunya untuk perkembangan dan kemajuan dunia bisnis (Wulandari dan Raharja, 2013).

(Chen et al., 2014) mengatakan bahwa perusahaan yang memiliki koneksi di dunia politik dapat dengan mudah mendapatkan akses mulai dari perizinan, informasi dan kebijakan melalui pemerintah sehingga dapat mempermudah perusahaan dalam melakukan bisnis yang berdampak pada kenaikan keuntungan perusahaan tersebut. Menurut penelitian yang dilakukan oleh Faccio (2006) sebuah perusahaan dapat dikatakan berkoneksi dengan tokoh politik apabila salah satu pemegang saham atau petinggi perusahaan merupakan tokoh politik atau memiliki hubungan khusus dengan pejabat pemerintahan. Habib, et al (2017), mengungkapkan bahwa ada beberapa hal yang menyebabkan perusahaan memiliki asosiasi politik, terutama ketika pasar tidak berjalan dengan baik sehingga membuat perusahaan mengambil langkah dengan bekerja sama dengan pihak pemerintah, seperti tarif pajakan, dan jaminan properti yang rendah sehingga perusahaan menggunakan koneksi politik untuk menguranginya. Kedua, perusahaan pada umumnya melakukan kerja sama dengan pihak pemerintah dikarenakan pemerintah mempunyai kontrol terhadap sumber daya sebuah negara. Ketiga, keuntungan sumber daya yang menunjukkan bahwa koneksi politik dapat membantu perusahaan dalam memperoleh sumber daya sebuah negara dengan lebih mudah.

Fisman (2001), koneksi politik antara pemerintah dengan pengusaha menimbulkan distribusi sumber daya yang tidak seimbang dan membuat ketergantungan politisi atau pejabat pemerintah terhadap korporasi bisnis yang mengharapkan memberikan mereka dana politik dan perusahaan juga mengharapkan pejabat pemerintah memberikan kebijakan yang dapat menguntungkan bagi perusahaan itu sendiri. Menurut penelitian yang di lakukan oleh Mobarak dan Purbasari (2006) dalam penelitiannya mengungkapkan bahwa di Indonesia, perusahaan yang secara tegas diidentikkan dengan sistem Soeharto memiliki keuntungan tersendiri dalam memperoleh izin impor dibandingkan dengan pesaingnya yang tidak memiliki hubungan dengan Soeharto. Hubungan politik perusahaan memiliki dampak yang berbeda-beda terhadap perusahaan. Fisman (2001) menjelaskan dalam penelitiannya bahwa perusahaan yang memiliki kedekatan dengan presiden Soeharto memperoleh dampak signifikan terhadap nilai perusahaan saat presiden Soeharto lengser dari kursi jabatannya (Soeharto Depedency Index) justru perusahaan yang memiliki hubungan politik dengan mantan presiden Soeharto tidak memiliki dampak signifikan terhadap nilai perusahaan tersebut. Perusahaan yang mayoritas sahamnya dimiliki oleh pemerintah dapat dikatakan sebagai perusahaan milik pemerintah seperti BUMN dan BUMD, sehingga dilibatkan oleh tokoh-tokoh politik yang ditunjuk oleh badan publik untuk mengawasi perusahaan negara atau BUMN (Gomez dan Jomo, 1997).

Penelitian yang di lakukan oleh Coulamb dan Sagnier (2014) menunjukkan bahwa terdapat peningkatan harga saham untuk perusahaan yang memiliki hubungan dengan pemilihan Presiden Perancis pada tahun 2007, dan pernyataan tersebut diperkuat oleh Wang et al. (2018), yang menunjukkan bahwa kehilangan asosiasi politik menyebabkan penurunan total pengembalian yang tidak biasa, dan ketika otoritas individu yang terkait dengan perusahaan telah mengundurkan diri dari pekerjaan mereka dan nilai-nilai perusahaan telah berkurang. Goldman dkk. (2009) menunjukkan bahwa hubungan politik berdampak pada kenaikan harga saham selama pemilihan presiden yang dibuktikan dengan kenaikan harga saham perusahaan yang berkoneksi dengan politik, sedangkan 
perusahaan yang tidak terkait secara politik tidak berpengaruh pada peningkatan harga saham perusahaan tersebut. Menurut penelitian yang dilakukan oleh Luhur (2010), pengujian kandungan informasi dilakukan untuk melihat seberapa berpengaruh sebuah peristiwa terhadap reaksi pasar terhadap suatu pengumuman, jika sebuah peristiwa mengandung informasi positif maka diharapkan berdampak baik bagi pasar modal dan begitu juga sebaliknya.

Untuk melihat apakah terdapat perbedaan CAR dan TVA perusahaan yang berafiliasi pemenang pemilihan umum 2019. Budiarto dan Baridwan (2009), menyatakan bahwa reaksi pasar sebagai suatu sinyal terhadap informasi adanya suatu peristiwa tertentu yang mempengaruhi harga saham dan Trading Volume Activity perusahaan tertentu. Maka dari itu peristiwa politik seperti pemilihan umum merupakan salah satu peristiwa yang dapat mempengaruhi reaksi pasar. Menurut penelitian yang dilakukan oleh Pamungkas Dkk (2015) terdapat perbedaan Cumulative Abnormal Return dan Trading Volume Activity pada sebelum dan sesudah pemilihan umum pada tahun 2014. Sedangkan penelitian yang di lakukan oleh Mansur dan Jumaili (2014) menemukan hasil yang sedikit berbeda yaitu tidak terdapat perbedaan yang signifikan dari rata-rata TVA pada pemilihan umum 2014. Ini dikarenakan terdapat perbedaan sampel penelitian yang dilakukan oleh para peneliti tersebut.

Dalam penelitian yang di lakukan oleh Do, Lee, dan Nguyen (2015) meneliti dampak koneksi politik terhadap pemilihan gubernur di Amerika selama periode 1999 sampai 2010 dengan ketatnya transparansi di Amerika sehingga terkadang koneksi politik di Amerika terabaikan begitu saja dan hasilnya selama periode penelitian terdapat kenaikan nilai Cumulative Abnormal Return sebesar $1,36 \%$ terhadap pemenang pemilihan gubernur di setiap periode pemilihan. Maka dari itu setiap terjadinya peristiwa politik seperti pemilihan presiden dapat mempengaruhi reaksi pasar. Di Indonesia dengan melihat koalisi pemenang pemilihan umum dalam penelitian ini untuk melihat apakah political connection berdasarkan peristiwa politik di Indonesia dapat memberikan perbedaan sebelum dan sesudah pengumuman resmi yang di lakukan oleh KPU dan MK dengan melihat Cumulative Abnormal Return (CAR) dan Trading Volume Activity (TVA).

Dilakukannya penelitian ini untuk mengetahui efek terbentuknya afiliasi antara perusahaan dengan politik melalui dewan komisaris, dewan direksi, dan pemegang saham dalam mempengaruhi (CAR) dan (TVA). Maka akan melakukan kajian untuk perusahaan- perusahaan terkoneksi pada pemenang pemilihan umum yang terjadi di Indonesia, yaitu mengenai adakah perbedaan antara hubungan politik dan struktur kepemilikan di perusahaan dengan Cumulative Abnormal Return (CAR) dan Trading Volume Activity (TVA) sebelum dan sesudah pengumuman KPU dan MK yang dilihat dari uji beda Cumulative Abnormal Return (CAR) dan Trading Volume Activity (TVA).

\section{Tinjauan pustaka dan pengembangan hipotesis \\ 2.1. Landasan teori}

\subsubsection{Political connection}

Asosiasi politik sebagaimana diindikasikan oleh Faccio (2006) adalah jika pemegang saham utama atau otoritas perusahaan adalah individu dari parlemen, kepala negara, yang diidentifikasi dengan otoritas negara, yayasan negara. Dalam kajian ini, Faccio juga mengisolasi gagasan asosiasi politik, yaitu hubungan timbal balik yang dapat terjadi khususnya:

a. Dalam hal perusahaan tidak langsung berhubungan dengan direktur atau presiden yang nama belakangnya sama dengan nama pengurus senior atau sebagian besar investor perusahaan.

b. The Economist atau Fortune memiliki hubungan yang bersahabat dengan tokoh politik, presiden, atau individu dari parlemen.

Darendeli dan Hill (2016) berpendapat bahwa hubungan politik rahasia antara pejabat senior perusahaan dan otoritas pemerintah. Perusahaan yang memiliki hubungan politik merupakan perusahaan atau kombinasi yang memiliki kedekatan dengan otoritas publik. Perusahaan yang memiliki kedekatan yang erat dengan otoritas publik dapat diartikan sebagai perusahaan yang diklaim oleh pemerintah, khususnya perusahaan sebagai badan usaha milik negara atau badan usaha milik daerah. Sementara itu, owner yang memiliki hubungan dekat dengan otoritas publik adalah kombinasi atau pemilik perusahaan yang merupakan tokoh politik yang mencolok (Gomez dan Jomo, 1997). 


\subsubsection{Event study}

Event study yang dirujuk oleh Peterson (1989) dan Kritziman (1994) yang dikutip dalam artikel Gudono dan Sugeng (1998) merupakan suatu teknik pengujian untuk melihat pengaruh suatu kejadian terhadap biaya saham di pasar modal. Persepsi ini umumnya dilakukan dengan mengamati return saham pada saat-saat tertentu. Sejalan dengan hal tersebut, Jogiyanto (2008) menyatakan bahwa studi kesempatan adalah investigasi yang mengkaji respons pasar terhadap suatu peristiwa yang datanya didistribusikan sebagai deklarasi. Harijono (1999) menyatakan bahwa studi kesempatan merupakan suatu investigasi terhadap perkembangan return saham yang terjadi di sekitar kesempatan metodis tertentu, khususnya deklarasi peristiwa yang dianggap dapat memberikan data baru tentang suatu perusahaan.

\subsubsection{Teori stakeholder}

Teori ini menyatakan bahwa seluruh stakeholder memiliki hak untuk memperoleh informasi tentang bagaimana aktivitas perusahaan dan bahkan mereka bias menggunakan informasi tersebut untuk menjaga kelangsungan dan perkembangan perusahaan (Deegan, 2004 ).

\subsubsection{Signalling theory}

pertama kali diperkenalkan oleh Spence (1973)mengatakan dalam penelitiannya bahwa suatu sinyal yang memberikan suatu sinyal, pihak pengirim (pemilik informasi) berusaha memberikan potongan informasi relevan yang dapat dimanfaatkan oleh pihak penerima. Pihak yang mendapat informasi kemudian akan menyesuaikan perilakunya sesuai dengan pemahamannya terhadap sinyal tersebut. Signaling theory mengemukakan tentang bagaimana seharusnya sebuah perusahaan memberikan sinyal kepada pengguna laporan keuangan. Sinyal ini berupa informasi mengenai apa yang sudah dilakukan oleh manajemen untuk merealisasikan keinginan pemilik. Sinyal dapat berupa promosi atau informasi lain yang menyatakan bahwa perusahaan tersebut lebih baik dari pada perusahaan lain.

\subsubsection{Abnormal Return}

Menurut Jogiyanto (2014), abnormal return merupakan kelebihan dari return yang sesungguhnya yang terjadi pada return yang terjadi dipasar modal. Dengan demikian imbal hasil tidak normal (abnormal return) adalah selisih antara imbal hasil sesungguhnya yang terjadi dengan imbal hasil ekspektasi. Sehingga dapat dikatakan bahwa abnormal return terjadi karena dipicu oleh adanya suatu peristiwa tertentu, misalnya suasana politik, hari libur nasional, kejadian besar, stock split, penawaran perdana saham perusahaan, suspend dan lain-lain.

$$
\text { RTNit=Rit }-E \text { (Rit) }
$$

(Hartono, 2013)

Keterangan:

RTNit : abnormal return sekuritas ke-i pada peristiwa ke-t

Rit : return sesungguhnya untuk sekuritas ke-i pada peristiwa ke-t

$\mathrm{E}($ Rit $)$ : return ekspektasi sekuritas ke-i untuk periode peristiwa ke-t

\subsubsection{Cumulative Abnormal Return (CAR)}

Suaryana (2008) mengatakan bahwa pengembalian yang tidak biasa menunjukkan reaksi pasar terhadap suatu peristiwa. Dengan demikian, gabungan pengembalian tidak biasa adalah pengembalian yang tidak diharapkan dan melebihi agregat harian. Dalam pemanfaatan kerangka waktu pencanangan putusan politik resmi yang dipimpin oleh KPU dan Mahkamah Konstitusi dalam hal pengangkatan resmi Republik Indonesia. Untuk mengetahui angka antisipasi return, Brown dan Warner (dalam Michael Hendrawijaya, 2009) dapat ditentukan atau didapatkan dengan memanfaatkan tiga model yaitu Mean-Adjusted Model, Market Model dan Market Changes Model. 
Rumus Abnormal Return:

RTNit=Rit $-E($ Rit $)$

Perhitungan Cumulative Abnormal Return:

$\mathrm{CAR}=\sum R T N i t$

\subsubsection{Trading Volume Activity (TVA)}

Sebagaimana dikatakan oleh Neni dan Mahendra (2004) volume perdagangan merupakan bagian yang di terima dalam analisis teknikal, kegiatan perdagangan dalam volume yang sangat tinggi di suatu bursa akan didefinisikan sebagai tanda pasar akan membaik. Foster (1986) dalam Sri, dkk. Mengatakan bahwa kenaikan dan penurunan volume transaksi saham dapat dilihat dengan menggunakan indikator aktivitas volume perdagangan TVA dengan rumus sebagai berikut:

$\mathrm{TVA}=\frac{\sum \text { sahamiditransaksit }}{\text { Ssahamiberedarwaktut }}$

\subsection{Penelitian terdahulu}

James S. Ang, David K. Ding dan Tiong Yang Thong (2013), dengan judul penelitian yaitu political connection and firm value pada Asian development review. Dengan hasil pemeriksaan tersebut, perusahaan yang secara fundamental mempengaruhi nilai perusahaan terkait dengan masalah legislatif atau perusahaan yang memiliki staf manajerial puncak terkait dengan masalah pemerintahan. Dalam penelitian yang dilakukan oleh Bianchi dan Viana (2014), dengan judul penelitian political connections: Evidence from listed companies in Portugal, dengan hasil dengan hasil penelitian yang diidentifikasi mempengaruhi nilai perusahaan dimana perusahaan yang terkait dengan masalah legislatif menunjukkan nilai perusahaan yang lebih tinggi daripada perusahaan yang terpisah.

Menurut penelitian Faccio(2002) dengan judul penelitian yaitu Politically-connected firms: Can they squeeze the State?, dengan hasil penelitian yaitu Perusahaan yang terhubung mengambil manfaat signifikan dalam hal leverage yang lebih tinggi, pajak yang lebih rendah, dan kekuatan pasar yang lebih kuat. Rata-rata, leverage 2,7 poin persentase lebih tinggi dalam struktur modal perusahaan yang terhubung. Perusahaan yang terhubung juga menikmati pajak yang lebih rendah sebesar 0,76 poin persentase.

Lee, Y. T., Nguyen, B. D., \& Do, Q. A (2013),dengan judul penelitian yaitu Political Connections and Firm Value: Evidence from the Regression Discontinuity Design of Close Gubernatorial Elections, dengan hasil penelitian yaitu Perusahaan yang terhubung dengan pemenang pemilihan gubernur memiliki signifikansi Cumulative Abnormal Return di bandingkan dengan perusahaan yang terhubung dengan yang kalah dalam pemilihan gubernur. perusahaan yang terhubung dengan pemenang dalam pemilihan umum berinvestasi $34,4 \%$ lebih banyak daripada perusahaan yang terhubung dengan pihak yang kalah.

Pronayuda (2006), dengan judul penelitian Analisis reaksi pasar terhadap bursa efek Jakarta terhadap pengumuman Indonesia bersatu, memberikan hasil bahwa peristiwa tersebut mempengaruhi perubahan-perubahan di Bursa Efek Jakarta apabila dilihat dari sisi aktivitas perdagangan di pasar modal. Dengan kata lain bahwa pasar modal Indonesia bereaksi terhadap peristiwa pengumuman Kabinet Indonesia Bersatu yang terlihat dari adanya perbedaan rata-rata Trading Volume Activity sebelum dan setelah pengumuman bagi perusahaan yang memiliki market kapitalisasi besar. Namun tidak halnya bagi perusahaan yang memiliki market kapitalisasi kecil.

Suryawijaya dan Setiawan (1998), dengan judul penelitian yaitu reaksi BEJ terhadap perisiwa 27 Juli 1996 (Peristiwa kudeta kantor pusat salah satu partai politik di Indonesia oleh dua kelompok yang didukung oleh massa yang besar). Hasil penelitian menunjukkan bahwa terdapat perbedaan variabel transaksi saham sebelum dan sesudah peristiwa kudeta kantor pusat salah satu partai di Indonesia pada Trading Volume Activity. 


\subsection{Pengembangan hipotesis}

H1: Terdapat perbedaan Cumulative Abnormal Return (CAR) yang signifikan terhadap perusahaan yang memiliki hubungan dengan pemenang pemilihan presiden sebelum dan sesudah pengumuman oleh Komisi Pemilihan Umum (KPU).

H2: Terdapat perbedaan Cumulative Abnormal Return (CAR) yang signifikan terhadap perusahaan yang memiliki hubungan dengan pemenang pemilihan presiden sebelum dan sesudah pengumuman oleh Mahkamah Konstitusi (MK).

H3: Terdapat perbedaan Trading Volume Activity (TVA) yang signifikan terhadap perusahaan yang memiliki hubungan dengan pemenang pemilihan presiden sebelum dan sesudah pengumuman oleh Komisi Pemilihan Umum (KPU).

H4: Terdapat perbedaan Trading Volume Activity (TVA) yang signifikan terhadap perusahaan yang memiliki hubungan dengan pemenang pemilihan presiden sebelum dan sesudah pengumuman oleh Mahkamah Konstitusi (MK).

\section{Metode penelitian}

Penelitian ini menggunakan metode kuantitatif dan termasuk ke dalam jenis penelitian deskriptif komparatif. Pendekatan yang digunakan adalah studi peristiwa (event study), yaitu metodologi yang digunakan untuk mempelajari reaksi pasar terhadap suatu peristiwa yang informasinya dipublikasikan sebagai suatu pengumuman. Event study dapat digunakan untuk menguji kandungan informasi (information content) dari suatu pengumuman dan dapat juga digunakan untuk menguji efisiensi pasar bentuk setengah kuat (Hartono, 2013). Jangka waktu yang digunakan untuk penelitian mulai dari pemilihan presiden sampai dengan pengumuman di umumkan oleh Mahkamah Konstitusi, berikut susunan penelitian:

1. Tanggal 22 Mei 2019 pengumuman hasil pemilihan presiden oleh KPU.

2. Tanggal 27 Juni 2019 pengumuman pemenang sengketa pemilihan presiden oleh MK.

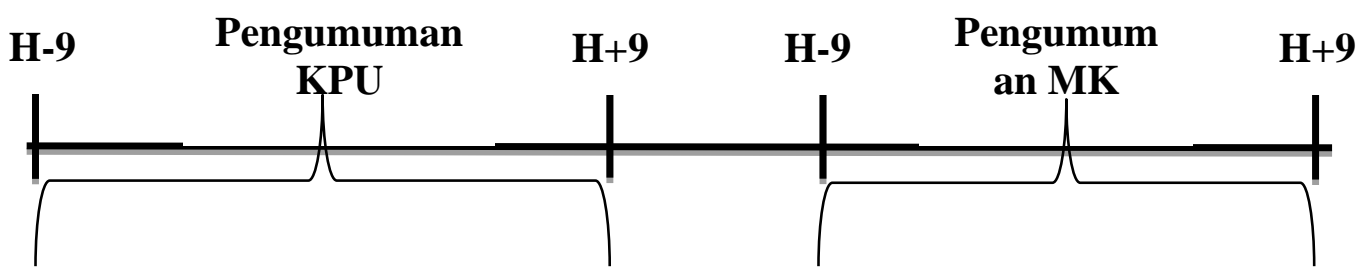

Gambar 1. Waktu pengamatan

Sumber data dalam penelitian ini memakai data yang dipublikasikan di website Bursa Efek Indonesia www.idx.co.id dan website resmi Komisi Pemilihan Umum (KPU). Pemakaian website bursa efek Indonesia dalam pengambilan data penelitian dikarenakan menyediakan berbagai informasi dan data yang di perlukan dan KPU merupakan website resmi yang memberikan informasi yang bersifat valid dan dapat dipercaya Populasi sampel dalam penelitian ini adalah perusahaan yang telah IPO di Bursa Efek Indonesia (BEI) per tanggal 31 Desember 2018, sampel yang digunakan dalam penelitian adalah perusahaan yang sesuai dengan kriteria sebagai berikut:

1. Perusahaan memiliki data harga saham harian dan volume perdagangan harian.

2. Perusahaan memiliki data lengkap mengenai struktur perusahaan dan pemegang saham.

3. Perusahaan memikili hubungan dengan pasangan calon presiden jokowi-ma'ruf, yang dapat dilihat dari struktur perusahaan atau masuk kedalam tim pemenangan calon presiden dengan pemilik, pemegang saham, dan individu yang tergabung dalam struktur perusahaan-perusahaan (Bursa Efek Indonesia).

Tabel 1. Sampel penelitian

\begin{tabular}{|l|l|c|}
\hline No & Keterangan & Jumlah \\
\hline 1. & $\begin{array}{l}\text { Perusahaan yang telah terdaftar di BEI per 31 } \\
\text { Desember 2018 }\end{array}$ & 677 \\
\hline
\end{tabular}




\begin{tabular}{|l|l|c|}
\hline 2. & $\begin{array}{l}\text { Perusahaan yang terdaftar setelah 17 april } \\
2019\end{array}$ & (45) \\
\hline 3. & $\begin{array}{l}\text { Perusahaan yang tidak berkoneksi politik } \\
\text { dengan pemenang pemilihan umum }\end{array}$ & $(607)$ \\
\hline & Jumlah sampel yang diambil & 25 \\
\hline
\end{tabular}

\section{Hasil dan pembahasan \\ 4.1. Hasil \\ 4.1.1. Statistik deskriptif \\ 4.1.1.1. Cumulative Abnormal Return (CAR)}

Tabel 2. Hasil uji statistik deskriptif Cumulative Abnormal Return

\begin{tabular}{|l|l|l|l|l|l|}
\hline & N & Minimum & Maksimum & $\begin{array}{c}\text { Rata- } \\
\text { Rata }\end{array}$ & Std. Deviasi \\
\hline CAR sebelum pengumuman KPU & 25 & $-0,1779$ & 0,1862 & 0,010561 & 0,0824897 \\
\hline CAR sesudah pengumuman KPU & 25 & $-0,1876$ & 0,3231 & 0,037207 & 0,1152083 \\
\hline CAR sebelum pengumuman MK & 25 & $-0,1330$ & 0,2163 & 0,007752 & 0,0750419 \\
\hline CAR sesudah pengumuman MK & 25 & $-0,1012$ & 0,1763 & 0,004997 & 0,0642121 \\
\hline
\end{tabular}

Sumber : Data Olahan SPSS 26 (2020)

Efek samping yield faktual ekspresif menunjukkan variabel total oddreturn, nilai dasar gabungan return tidak biasa pada rentang waktu sebelum deklarasi KPU adalah - 0,1779 yang ditemukan di organisasi Semen Baturaja Tbk, sebelum deklarasi KPU dan yang paling ekstrim. senilai 0,1862 ditemukan di organisasi MNC Kapital. Indonesia Tbk, sebelum deklarasi KPU nilai normalnya adalah 0,010561 dengan standar deviasi 0,0824897. Dasar gabungan oddreturnesteem setelah deklarasi KPU adalah - 0,1876 yang terjadi di Bakrie Sumatra Plantations Tbk, setelah deklarasi KPU dan nilai terbesar adalah 0,3231 yang terjadi pada organisasi MNC Kapital Indonesia Tbk, setelah deklarasi KPU Nilai normal adalah 0, 037207 dan deviasi standar 0.1152083. Nilai dasar total oddreturn sebelum deklarasi MK adalah - 0,1330 terjadi di Global Mediacom Tbk, sebelum deklarasi MK dan nilai terbesar 0,2163 yang terjadi di organisasi Semen Baturaja Tbk. Nilai normal adalah 0,07752 dan standar deviasi 0,0750419. Nilai dasar agregat oddreturn setelah deklarasi MK adalah - 0,1012 yang terjadi di organisasi MNC Kapital Indonesia Tbk, setelah deklarasi MK dan nilai terbesar 0,1763 terdapat pada organisasi Media Nusantara Citra Tbk, nilai normal. adalah 0,04997 dan deviasi standar 0,0642121 .

\subsubsection{Trading Volume Activity (TVA)}

Tabel 3. Hasil uji statistik deskriptif Trading Volume Activity

\begin{tabular}{|l|l|l|l|l|l|}
\hline & \multicolumn{1}{|c|}{$\mathbf{N}$} & Minimum & Maksimum & $\begin{array}{c}\text { Rata- } \\
\text { Rata }\end{array}$ & Std. Deviasi \\
\hline TVA sebelum pengumuman KPU & 25 & 0,00000008 & 0,03288 & 0,00276 & 0,00659 \\
\hline TVA sesudah pengumuman KPU & 25 & 0,0000013 & 0,02106 & 0,00231 & 0,00419 \\
\hline TVA sebelum pengumuman MK & 25 & 0,0000014 & 0,02468 & 0,00274 & 0,00507 \\
\hline TVA sesudah pengumuman MK & 25 & 0,0000010 & 0,06650 & 0,00406 & 0,01313 \\
\hline
\end{tabular}

Sumber: Data olahan SPSS 26 (2020)

Efek samping dari hasil ilustratif faktual pada faktor-faktor tersebut menunjukkan bahwa volume aksi tukar sebelum deklarasi KPU menunjukkan nilai dasar sebesar 0,00008, secara mutlak pada organisasi Bank MNC International Tbk, dan nilai terbesar sebesar 0,03288 pada organisasi Mahaka Media Tbk, dengan nilai normal 0, 00276 dan harga deviasi standar adalah 0,00659. Setelah deklarasi KPU, insentif dasar untuk Aktivitas Volume Perdagangan adalah 0,0000013 di Bakrie and Brothers Tbk dan volume pertukaran paling ekstrem senilai 0,02106 ditemukan di Mahaka Media Tbk, dengan nilai normal 0,00231 dan standar deviasi 0,00419. Sebagai konsekuensi dari imbal hasil terukur yang berbeda sebelum deklarasi Mahkamah Agung (MK), nilai dasar adalah 0,0000014 di organisasi Bank MNC International Tbk, dan nilai Aktivitas Volume Perdagangan yang paling ekstrem adalah 0,02468 
di organisasi Mahaka Media Tbk, dengan nilai normal 0,00274 dan deviasi standar 0,00507. Sebagai akibat dari pengujian ekspresif terukur pada Aktivitas Volume Perdagangan setelah deklarasi Mahkamah Agung (MK), nilai dasar adalah 0,0000010 untuk organisasi Bakrie and Brothers Tbk, kemudian nilai terbesar adalah 0,06650 untuk organisasi Mahaka Media Tbk. , nilai normalnya adalah 0,00406 dan deviasi standar 0,01313.

\subsubsection{Uji Normalitas}

4.1.2.1. Uji Normalitas Cumulative Abnormal Return (CAR)

Tabel 4. Hasil uji normalitas Cumulative Abnormal Return

\begin{tabular}{|c|l|l|l|l|}
\hline \multirow{2}{*}{ Variable } & \multirow{2}{*}{ Periode } & \multicolumn{2}{|c|}{ TestShapiro-Wilk } & \multirow{2}{*}{ keterangan } \\
\cline { 3 - 5 } & & \multicolumn{1}{|c|}{ Statistik } & \multicolumn{1}{|c|}{ sig. } & \\
\cline { 2 - 5 } & Sebelum pengumuman KPU & 0,888 & 0,234 & Normal \\
\cline { 2 - 5 } $\begin{array}{c}\text { Cumulative } \\
\text { Abnormal } \\
\text { Return }\end{array}$ & Sesudah pengumuman KPU & 0,935 & 0,233 & Normal \\
\cline { 2 - 5 } & Sebelum pengumuman MK & 0,798 & 0,036 & $\begin{array}{l}\text { Tidak } \\
\text { Normal }\end{array}$ \\
\cline { 2 - 5 } & Sesudah pengumuman MK & 0,926 & 0,006 & $\begin{array}{l}\text { Tidak } \\
\text { Normal }\end{array}$ \\
\hline
\end{tabular}

Sumber: data olahan spss 26 (2020)

Tabel 4 menunjukkan hasil dari uji normalitas terhadap variabel Cumulative Abnormal Return dengan hasil pada sebelum pengumuman KPU memiliki signifikansi 0,234 dan sesudah pengumuman KPU memiliki nilai signifikansi sebesar 0,233. Hasil nilai signifikansi sebelum pengumuman MK sebesar 0,036 dan sesudah pengumuman MK memiliki nilai signifikansi sebesar 0,006. Hal ini menunjukkan bahwa signifikansi yang dihasilkan dari penelitian ini berada $>0,05$ atau lebih dari $5 \%$ yang berarti bahwa data residual berdistribusi normal. ada dua data terdistribusi normal yaitu pada saat sebelum pengumuman KPU dan sesudah pengumuman KPU namun secara keseluruhan data yang di tunjukkan oleh tabel 4 terdistribusi tidak normal maka akan dilakukan uji sampel berpasangan menggunakan uji Wilcoxon.

\subsubsection{Uji Normalitas Trading Volume Activity (TVA)}

Tabel 5. Hasil uji normalitas Trading Volume Activity

\begin{tabular}{|c|c|c|c|c|}
\hline Variable & \multirow{2}{*}{ Periode } & \multicolumn{2}{|c|}{ TestShapiro-Wilk } & \multirow{2}{*}{ Keterangan } \\
\hline \multirow{5}{*}{$\begin{array}{l}\text { Trading } \\
\text { Volume } \\
\text { Activity }\end{array}$} & & Statistik & sig. & \\
\hline & Sebelum pengumuman KPU & 0,430 & 0,000 & $\begin{array}{l}\text { Tidak } \\
\text { Normal }\end{array}$ \\
\hline & Sesudah pengumuman KPU & 0,513 & 0,000 & $\begin{array}{l}\text { Normal } \\
\text { Normal }\end{array}$ \\
\hline & $\begin{array}{l}\text { Sebelum pengumuman } \\
\text { MK }\end{array}$ & 0,542 & 0,000 & $\begin{array}{l}\text { Tidak } \\
\text { Normal }\end{array}$ \\
\hline & Sesudah pengumuman MK & 0,300 & 0,000 & $\begin{array}{l}\text { Tidak } \\
\text { Normal }\end{array}$ \\
\hline
\end{tabular}

Sumber: data olahan spss 26 (2020)

Dari hasil uji normalitas Trading Volume Activity data terdistribusi tidak normal dengan hasil sebelum pengumuman Komisi Pemilihan Umum (KPU) nilai signifikansi sebesar 0,000, setelah pengumuman Komisi Pemilihan Umum (KPU) dengan nilai signifikansi 0,000. Kemudian nilai signifikansi sebelum pengumuman Mahkamah Konstitusi (MK) sebesar 0,000 dan setelah Pengumuman Mahkamah Konstitusi (MK) nilai signifikansi sebesar 0,000. Syarat data terdistribusi dengan normal dengan syarat nilai signifikansi yang dihasilkan dari penelitian ini berada $>0,05$ atau lebih dari 5\% yang berarti bahwa data residual berdistribusi normal dan hasil dari penelitian ini data terdistribusi tidak normal. Berdasarkan hasil uji normalitas Trading Volume Activity dapat disimpulkan bahwa selanjutnya untuk pengujian hipotesis kedua variabel dapat dilakukan dengan uji non parametrik yaitu uji beda dua sampel berpasangan dengan menggunakan uji wilcoxon. Uji ini untuk melihat signifikansi rata-rata harian dari Trading Volume Activity. 


\subsubsection{Uji Hipotesis}

4.1.3.1. Uji hipotesis Cumulative Abnormal Return (CAR)

Tabel 6. Hasil uji hipotesis Cumulative Abnormal Return

\begin{tabular}{|l|l|l|l|}
\hline \multicolumn{1}{|c|}{ Variabel } & \multicolumn{1}{|c|}{ Periode } & \multicolumn{2}{c|}{ Wilcoxon } \\
\cline { 3 - 4 } & & Z Hitung & \multicolumn{1}{c|}{ Sig. } \\
\hline \multirow{4}{*}{ Cumulative Abnormal Return } & Sebelum dan sesudah pengumuman KPU & $-1,224$ & \multirow{2}{*}{0,221} \\
\cline { 2 - 4 } & & & \\
& Sebelum dan sesudah pengumuman MK & $-0,848$ & 0,397 \\
& & & \\
\hline
\end{tabular}

Tabel 6 menunjukkan hasil dari uji beda Cumulative Abnormal Return sebelum dan sesudah pengumuman pemilihan presiden republik Indonesia yang di umumkan oleh KPU dan pengumuman sengketa pemilihan presiden oleh MK. Dilihat dari tabel tersebut, maka dapat dinilai bahwa terdapat hasil signifikansi sebelum dan sesudah pengumuman Komisi Pemilihan Umum (KPU) sebesar 0,221 $>5 \%$ yang artinya tidak terdapat signifikansi sebelum dan sesudah pengumuman Komisi Pemilihan Umum (KPU) pada Cumulative Abnormal Return sehingga H1 ditolak. Nilai signifikansi sebelum dan sesudah pengumuman Mahkamah Konstitusi (MK) sebesar 0,397 atau >5\% yang artinya hipotesis atau $\mathrm{H} 2$ ditolak.

4.1.3.2. Uji Hipotesis Trading Volume Activity (TVA)

Tabel 7. Hasil uji hipotesis Trading Volume Activity

\begin{tabular}{|l|l|l|l|}
\hline \multirow{2}{*}{ Variabel } & \multicolumn{1}{|c|}{ Periode } & \multicolumn{2}{c|}{ Wilcoxon } \\
\cline { 3 - 4 } & & Z Hitung & \multicolumn{1}{c|}{ Sig. } \\
\hline \multirow{3}{*}{ Trading Volume Activity } & Sebelum dan sesudah pengumuman KPU & $-0,363$ & \multirow{2}{*}{0,716} \\
\cline { 2 - 4 } & Sebelum dan sesudah pengumuman MK & $-1,978$ & 0,048 \\
& & & \\
\hline
\end{tabular}

Dari hasil uji hipotesis pada table 4.3.2 dapat di tarik hasil bahwa tidak ada pengaruh nilai signifikansi antara sebelum dan sesudah pengumuman KPU karena nilai signifikansi hanya 0,716 sehingga $\mathrm{H} 3$ ditolak, alasan tidak adanya pengaruh perbedaan sebelum dan sesudah pengumuman KPU dari Trading Volume Activity karena data terdistribusi normal dengan menentukan persentase kepercayaan sebesar $95 \%$ dan tingkat kesalahan $\alpha$ sebesar $5 \%$. Jika nilai signifikan $<0,05$ maka hipotesis diterima, tetapi jika nilai signifikan $>0,05$ maka hipotesis yang di ajukan ditolak.

Hasil uji beda sebelum dan sesudah pengumuman MK dengan menggunakan uji wilcoxon pada Trading Volume Activity juga memiliki nilai signifikansi sebesar 0,048 atau >0,05 maka terdapat pengaruh Trading Volume Activity sebelum dan sesudah pengumuman Mahkamah Konstitusi (MK) dan hipotesis atau $\mathrm{H} 4$ di diterima. Hal ini dikarenakan setelah pengumuman oleh KPU terdapat sengketa pemilihan presiden yang membuat investor masih menunggu keputusan akhir dari kontestasi pemilihan presiden, rata-rata trading volume 25 perusahaan yang berkoneksi pada pemenang presiden sebelum pengumuman MK sebesar 0,00274 dan setelah keluarnya putusan Mahkamah Konstitusi 
yang menyatakan bahwa Jokowi-Ma'ruf menang dalam pemilihan presiden 2019 rata-rata Trading Volume Activity naik menjadi 0,00406 yang terdapat pada tabel 3. Namun hal ini tidak memberikan dampak pada CAR perusahaan yang berkoneksi pada pemenang pemilihan presiden 2019.

\subsection{Pembahasan}

4.2.1 Cumulative Abnormal Return dan koneksi politik perusahaan dengan pemenang pemilihan presiden 2019.

Menurut Pahala,dkk (2012), dalam penelitiannya mengatakan bahwa Cumulative Abnormal Return merupakan kumulatif harian dari abnormal return. Menurut Hartono (2013) abnormal return adalah selisih antara tingkat keuntungan sebenarnya (actual return) dengan tingkat keuntungan yang diharapkan (expected return). Pemilihan presiden 2019 merupakan sebuah peristiwa yang rutin di lakukan setiap lima tahun sekali di Indonesia, perubahan tampuk kepemimpinan di harapkan mampu memberikan angin segar bagi para pelaku usaha, sehingga peristiwa ini sangat di nanti-nanti oleh para investor, karena bagaimana sebuah pemerintahan baru memberikan regulasi dalam kebijakan negara dan khususnya ekonomi, terpilihnya Jokowi sebagai presiden kembali untuk yang kedua kalinya tidak memberikan efek signifikan Pada perusahaan-perusahaan yang mendukung Jokowi pada pemilihan presiden 2019 ini, ini di buktikan dengan tidak ada nilai signifikansi dari uji hipotesis Cumulative Abnormal Return yang memiliki nilai signifikansi $>0,05$.

Aggarwal, dkk (2012), mengatakan perusahaan di Amerika melakukan pendanaan kepada partai politik, ini akan merugikan perusahaan tersebut baik jangka panjang maupun jangka pendek sehingga terjadi keraguan dimata investor ketika sebuah perusahaan berkoneksi dengan pemerintah yang menyebabkan terjadinya penurunan harga saham bagi perusahaan yang melakukan pembiayaan pemilihan umum di Amerika.47 Maulana dan Wati (2019) Peristiwa pemilihan umum presiden pemilihan presiden merupakan salah satu titik kulminasi dalam rangkaian peristiwa politik di suatu negara sehingga Investor tentunya menginginkan risiko yang paling rendah dalam melakukan investasi, sehingga adanya peristiwa pemilu presiden dan wakil presiden akan membuat investor cenderung berhati-hati dalam menginvestasikan dananya ke pasar modal.

\subsubsection{Trading Volume Activity dan koneksi politik perusahaan dengan pemenang pemilihan presiden} 2019

Berdasarkan tabel 7, hasil uji wilcoxon membuktikan bahwa tidak ada nilai signifikansi pada periode sebelum dan sesudah pengumuman Komisi Pemilihan Umum (KPU) dan Mahkamah Konstitusi (MK). Walaupun peristiwa pemilihan presiden merupakan sebuah peristiwa besar namun bagi perusahaan yang mendukung pemenang pemilihan umum tidak ada kenaikan penjualan saham pada periode penelitian, hal ini di buktikan dengan hasil uji hipotesis pada Trading Volume Activity memiliki hasil $>0,05$ pada sebelum dan sesudah pengumuman KPU sehingga hipotesis ditolak. Jensen dan Meckling, (1976) menjelaskan bahwa perbedaan kepentingan antara manajer dan pemegang saham akan menimbulkan agency conflict, hal tersebut terjadi karena manajer mengutamakan kepentingan pribadi, sebaliknya pemegang saham tidak menyukai kepentingan pribadi dari manajer karena apa yang dilakukan manajer tersebut akan menambah biaya bagi perusahaan sehingga menyebabkan penurunan keuntungan perusahaan dan berpengaruh terhadap harga saham sehingga yang tercermin dari TVA48 Pada sebelum dan sesudah pengumuman MK terdapat signifikansi sebesar 0,048 sehingga terdapat perbedaan signifikansi sebelum dan sesudah pengumuman MK.

Dengan naiknya Trading Volume Activity tidak mempengaruhi kenaikan Cumulative Abnormal Return. Kemenangan Jokowi-Ma'aruf dalam sidang gugatan sengketa pemiihan presiden yang di umumkan oleh Mahkamah Konstitusi (MK), di tandai dengan naiknya Trading Volume Activity perusahaan yang terkoneksi dengan Jokowi-Ma'aruf yang di tandakan dengan adanya signifikansi dari TVA sebelum dan setelah pengumuman Mahkamah Konstitusi (MK). Hal ini di karenakan investor masih melakukan aksi wait and see dikarenakan setelah pengumuman oleh Komisi Pemilihan Umum (KPU) terdapat gugatan yang di lakukan oleh Prabowo-Sandiaga, sehingga setelah keluarnya kepastian pemenang pemilihan presiden yang di umumkan oleh Mahkamah Konstitusi (MK) membuat investor melakukan aksi beli saham perusahaan yang berkoneksi dengan Jokowi-Ma'aruf 
yang di buktikan dengan terdapat perbedaan nilai signifikansi sebelum dan sesudah pengumuman MK yang di buktikan dengan uji wilcoxon dengan nilai signifikansi sebesar 0,048 yang terdapat pada tabel 7.

\section{Kesimpulan}

Tidak semua peristiwa politik memberikan dampak baik bagi saham perusahaan yang memiliki hubungan dengan pemangku kepentingan. Investor cenderung mengambil keputusan menunda investasi sampai adanya keputusan pengumuman yang resmi. Pada penelitian ini setelah pengumuman sengketa pemilihan presiden 2019 volume perdagangan saham justru meningkat ini menandakan keputusan memberikan kepastian kepada investor untuk melakukan investasi. Meskipun setelah pengumuman KPU dan Setelah pengumuman MK IHSG mengalami kenaikan yang cukup signifikan namun itu tidak terjadi pada perusahaan yang berkoneksi pada pemenang pemilihan presiden 2019, ini dibuktikan dengan di tolaknya tiga hipotesis yang di ajukan dan hanya satu hipotesis yang diterima. Kenaikan volume perdagangan tidak membuat naiknya CAR, Sejalan dengan yang pernyataan Suryawijaya dan Setiawan (1998) kenaikan volume perdagangan tidak memberikan efek kenaikan harga saham keseluruhan pada sampel penelitian.

\section{Limitasi dan studi lanjutan}

Dalam penelitian ini yang menjadi limitasi adalah waktu pengamatan yang hanya 36 hari lebih, jumlah sampel yang terbatas yaitu hanya 25 perusahaan dengan ruang lingkup penelitian perusahaan yang memiliki afiliasi dengan pemenang pemilihan umum 2019 dan Tidak semua sistem politik setiap negara sama sehingga terdapat banyak perbedaan pada hasil penelitian ini dengan penelitian di luar negri. Untuk rencana ke depannya penulis berharap agar investor lebih berhati-hati dalam melakukan investasi dalam peristiwa yang penting karena tidak semua peristiwa dapat memberikan dampak positif bagi investor dan perusahaan itu sendiri, tetap melakukan analisa melalui laporan keuangan perusahaan dan menganalisis bagaimana potensi prospek jangka panjang perusahaan yang akan di investasikan.

\section{Ucapan terima kasih}

Puja dan puji syukur ke Hadirat Tuhan Yang Maha Esa yang mana telah memberikan kami segala kemudahan dalam menyelesaikan penelitian ini dalam waktu yang sesingkat-sesingkatnya. Tak lupa ucapan terima kasih kami haturkan dengan tulus kepada Bapak Dr. Sudrajat, S.E., M.Acc., Akt dan bapak Pigo Nauli, S.E.,.M.Si. selaku pembimbing tugas ujian akhir, kemudian kepada bapak Prof. Yuliansyah, SE, M.S.A., Ph.D., Akt., CA. selaku pembahas tugas ujian akhir. Meskipun Artikel saya masih jauh dari kata sempurna, Semoga hasil yang di dapatkan sebaik kerja keras yang telah saya berikan untuk pembuatan artikel ini. Sekian dan Terima kasih.

\section{Referensi}

Aggarwal, R.K., Meschke, F., \& Wang, T.Y. (2012). Corporate political donations: investment or agency?. Business and Politics, 14 .

Ang, James S., David K. Ding, and Tiong Yang Thong. (2013). Political connection and firm value. Asian Development Review 30.2 (2013): 131-166.

Asmita, Melia. (2005). Reaksi pasar modal Indonesia terhadap pemilu 2004 (Studi kasus saham lq 45 dibursaef fek Jakarta). Masters thesis, program pascasarjana Universitas Diponegoro.

Bianchi, MariaT., Rui Couto V. (2014). Political connections: Evidence from listed companies in Portugal. International Journal of Economics and Accounting, 5(1):75.

Budiarto, Arif dan Zaki Baridwan. 1999. Pengaruh Pengumuman RightIssue Terhadap Tingkat Keuntungan dan Likuiditas Saham di Bursa Efek Jakarta Periode 1994-1996. Jurnal Riset Akuntansi Indonesia Vol.2 No.1 (Januari): 91-116.

Chen,Y., Luo,D. AndLi,W., (2014). Political connections, entry barriers, and firm performance. Chinese management studies, 8 (3), pp. 473-486.

Coulumb, Renaud, dan Marc Sangnier. (2014). The impact of political majorities on firm value: Do electoral promises or friendship connections matter? Journal of public economics 115 (2014): 158-170. 
Darendeli, I. S., \& Hill, T. L. (2016). Uncovering the complex relationships between political risk and MNE firm legitimacy: Insights from Libya. Journal of International Business Studies, 47(1), 68-92.

Deegan, C. (2004). Environmental disclosures and share prices - a discussion about efforts to study this relationship. Accounting forum (Vol.28, No.1, pp.87-97). Taylor \& Francis.

Deegan,C.(2004).Financial accounting theory. McGraw-Hill book company, Sydney.

Do, Quoc-Anh, Yen-TeikLee, Nguyen. (2012). Political connections and firm value: Evidence from close gubernatorial elections. SSRN electronic journal: 1-53.

Faccio, Mara. (2006). Politically connected firms. American economic review 96 (1): 369-386.

Fauzia, mutia. (2018). Kebijakan-kebijakan trump mengancam ekonomi global.19 Juli 2018. Jakarta.

Fisman, Raymond. (2001). Estimating the value of political connections. American economic review 91(4):1095-1102.

Foster, F.D., \& Viswanathan, S. (1993). Variations in trading volume, return volatility, and trading costs: Evidence on recent price formation models. The Journal of Finance, 48(1), 187-211.

Goldman, E., J. Rocholl, dan J.So. (2009). Do politically connected boards affect firm value?. The review of financial studies 22(6):2331-2360.

Gomez, T., \& Jomo, K.S. (1997). The political economy of Malaysia.

Gudono \& Sugeng. (1998). Reaksi pasar modal terhadap regulasi yang berkaitan dengan bantuan sosial. Kompak, Nomor 17 Oktober Hal 61-78.

Habib, A., Muhammadi, A.H., \& Jiang, H. (2017). Political connections related party transactions, and auditor choice: Evidence from Indonesia. Journal of contemporary accounting and economics.

Harijono. (1999). Event study. Cetakan pertama. Fakultas Ekonomi Universitas Kristen Satya Wacana. Salatiga.

Harjito, A., dan Martono. (2005). Manajemen keuangan.Yogyakarta.

Hartono, Jogiyanto.(2010). Teori portofolio dan analisis investasi. Yogyakarta: BPFE UGM, edisi7.

Hendrawijaya Dj, M. (2009). Analisis perbandingan harga saham, volume perdagangan saham, dan abnormal return saham sebelum dan sesudah pemecahan saham (Studi pada perusahaan gopublic yang melakukan pemecahan saham antara tahun 2005-2008 di BEI) (Doctoraldissertation, program Pascasarjana Universitas Diponegoro).

Jensen, M. C., \& Meckling, W. H. (1976). Theory of the firm: Managerial behavior, agency costs and ownership structure. Journal of financial economics, 3(4), 305-360.

Jogiyanto H.M. (2009). Teori portofolio dan analisis investasi. Edisi ketiga. Yogyakarta: BPFE.

Lee, Y. T., Nguyen, B. D., \& Do, Q. A. (2013). Political connections and firm value: evidence from the regression discontinuity design of close gubernatorial elections (No. 15). Sciences Po Departement of Economics.

Luhur,S.(2010). Reaksi pasar modal Indonesia seputar pemilihan umum 8 Juli 2009 pada saham LQ45. Jurnal keuangan dan perbankan, 14(2), 249-262.

Mansur, F., \& Jumaili,S. (2014). Reaksi pasar modal terhadap peristiwa pemilihan umum tahun 2014 pada perusahaan terdaftar dibursa efek Indonesia. Jurnal penelitian Universitas Jambi: seri humaniora, 16(2), 43448.

Maulana, A., \& Wati, L. N. (2019). Pengaruh koneksi politik dan struktur kepemilikan manajerial terhadap nilai perusahaan. Jurnal Akuntansi, 8(1), 1-12.

Mobarak, A.M., \& Purbasari, D.P. (2006).Corrupt protection for sale to firms: Evidence from Indonesia. Unpublished manuscript. University of Colorado at Boulder, Colorado.

Neni \& Mahendra Harimawan, (2004). Pengaruh pemilihan umum legislatif Indonesia tahun 2003 terhadap return saham dan volume perdagangan saham LQ-45 di PT. Bursa Efek Jakarta (BEJ). Sinergi: Kajian bisnis dan manajemen, vol.7, No.1, 2004, hal.89-101.

Pahala, I., Jaya, T.E., \& Meilisa, G.O. (2012). Pengaruh perbedaan laba akuntansi dan laba fiskal serta roa terhadap Cumulative Abnormal Return pada perusahaan manufaktur yang terdaftar dibursa efek Indonesia pada tahun2009. Jurnal ilmiah econosains, 10(2), 170-192.

Pamungkas, A. (2015). Pengaruh pemilu presiden Indonesia tahun 2014 terhadap abnormal return dan Trading Volume Activity (studi pada perusahaan pada perusahaan yang tercatat sebagai anggota indeks kompas 100). Jurnal administrasi bisnis, 21(2). 
Pronayuda, Teddi. (2006). Analisis reaksi pasar terhadap peristiwa pengumuman kabinet Indonesia bersatu. Skripsi Fakultas Ekonomi Universitas Islam Indonesia, Yogyakarta.

Spence, A.M. (1973). Job market signaling. Quarrterly journal of economics.

Suaryana, A. (2008). Pengaruh konservatisme laba terhadap koefisien respon laba. Jurnal akuntansi dan bisnis, 3(1).

Suryawijaya, M. A., dan Setiawan. (1998). Reaksi pasar modal Indonesia terhadap peristiwa politik dalam negeri, event study pada peristiwa 27 juli 1996. Kelola No. 18/VII/1998, h 137-153

Undang-UndangRepublikIndonesiaNomor40Tahun2007Tentang Perseroan Terbatas Pasal 1. www.ojk.go.id / sustainable-finance/ id/ peraturan/ undang- undang /Pages /UndangUndang- No.-40-tahun-2007-tentang-PerseroanTerbatas.aspx. Diakses pada 18 Januari 2020.

Wang, Fangjun, Luying Xu, Junrui Zhang, WeiShu. (2018). Political connection, internal control and firm value: Evidence from China's anti-corruption campaign. Journal of business research 86(1): 53-67.

Wulandari, Tri, Raharja.(2013).Analisis pengaruh political connection dan struktur kepemilikan terhadapkinerjaperusahaan. Diponegoro Journal of Accounting 2(1):1-12.

www.idx.co.id. Diakses pada 23 Agustus 2020. 